\title{
The hypaxial origin of the epaxially located rhomboid muscles
}

Article

Accepted Version

Creative Commons: Attribution-Noncommercial-No Derivative Works 4.0

Saberi, M., Qin, P., Valasek, P., Norizadeh-Abbariki, T., Patel, K. and Huang, R. (2017) The hypaxial origin of the epaxially located rhomboid muscles. Annals of Anatomy, 214. pp. 15-20. ISSN 1618-0402 doi:

https://doi.org/10.1016/j.aanat.2017.05.009 Available at https://centaur.reading.ac.uk/70971/

It is advisable to refer to the publisher's version if you intend to cite from the work. See Guidance on citing.

To link to this article DOI: http://dx.doi.org/10.1016/j.aanat.2017.05.009

Publisher: Elsevier

All outputs in CentAUR are protected by Intellectual Property Rights law, including copyright law. Copyright and IPR is retained by the creators or other copyright holders. Terms and conditions for use of this material are defined in the End User Agreement.

\section{www.reading.ac.uk/centaur}

\section{CentAUR}

Central Archive at the University of Reading 
Reading's research outputs online 
Anatomy

Elsevier Editorial System(tm) for Annals of

Manuscript Draft

Manuscript Number:

Title: The hypaxial origin of the epaxially located rhomboid muscles

Article Type: Research Article

Keywords: Rhomboid muscles, Quail-chick chimeras, Epaxial muscles, Hypaxial muscles

Corresponding Author: Dr. Ruijin Huang,

Corresponding Author's Institution: Institute of Anatomy

First Author: Ruijin Huang

Order of Authors: Ruijin Huang

Abstract: In vertebrates, skeletal muscles of the body are made up of epaxial and hypaxial muscles based on their innervation and relative position to the vertebral column. The epaxial muscles are innervated by the dorsal branches of the spinal nerves and comprise the intrinsic (deep) back muscles, while the hypaxial muscles are innervated by the ventral branches of the spinal nerves including the plexus and consist of a heterogeneous group of intercostal, abdominal, and limb as well as girdle muscles. The canonical view holds that the epaxial muscles are derived from the medial halves of the somites, whereas the hypaxial muscles are all derived from the lateral somitic halves. The rhomboid muscles are situated dorsal to the vertebral column and therefore in the domain typically occupied by epaxial muscles. However, they are innervated by a ventral branch of the brachial plexus called the $\mathrm{N}$. dorsalis scapulae. Due to the apparent inappropriate position of the muscle in relation to its innervation we investigated its origin to help clarify this issue. To study the embryonic origin of the rhomboid muscles, we followed derivatives of the medial and lateral somite halves using quail-chick chimeras. Our results showed that the rhomboid muscles are made up of cells derived mainly from the lateral portion of the somite. Therefore the rhomboid muscles which lie within the epaxial domain of the body, originate from the hypaxial domain of the somites. However, their connective tissue is derived from both medial and lateral somite. 
1 Short running page heading: Origin of rhomboid muscles

2

3 Title: The hypaxial origin of the epaxially located rhomboid muscles

4

5 Minu Saberi ${ }^{1,2}$, Qin Pu ${ }^{1,3}$, Petr Valasek ${ }^{4}$, Tannaz Norizadeh Abbariki ${ }^{1}$, Ketan Patel ${ }^{5}$, 6 Ruijin Huang 1,6 *

$7{ }^{1}$ Institute of Anatomy, Department of Neuroanatomy, Medical Faculty Bonn, Rheinische

8 Friedrich-Wilhelms-University of Bonn, Germany.

92 Current address: Department of Operative Dentistry and Periodontology, Medical Center10 University of Freiburg, Faculty of Medicine, Albert-Ludwigs-University, Freiburg, Germany

$11{ }^{3}$ Current address: Institute of Anatomy, Department of Anatomy and Molecular Embryology, 12 Ruhr-University Bochum, Germany.

$13{ }^{4}$ Institute of Anatomy, First Faculty of Medicine, Charles University, Prague, Czech Republic $14{ }^{5}$ School of Biological Sciences, University of Reading, UK

19

${ }^{6}$ Institute of Anatomy and Cell Biology, Department of Anatomy and Molecular Embryology,

University of Freiburg, Germany

*Corresponding author (ruijin.huang@uni-bonn.de) 


\section{Abstract}

2 In vertebrates, skeletal muscles of the body are made up of epaxial and hypaxial muscles

3 based on their innervation and relative position to the vertebral column. The epaxial muscles

4 are innervated by the dorsal branches of the spinal nerves and comprise the intrinsic (deep)

5 back muscles, while the hypaxial muscles are innervated by the ventral branches of the spinal

6 nerves including the plexus and consist of a heterogeneous group of intercostal, abdominal,

7 and limb as well as girdle muscles. The canonical view holds that the epaxial muscles are

8 derived from the medial halves of the somites, whereas the hypaxial muscles are all derived

9 from the lateral somitic halves. The rhomboid muscles are situated dorsal to the vertebral column and therefore in the domain typically occupied by epaxial muscles. However, they are innervated by a ventral branch of the brachial plexus called the N. dorsalis scapulae. Due to the apparent inappropriate position of the muscle in relation to its innervation we investigated its origin to help clarify this issue. To study the embryonic origin of the rhomboid muscles, we followed derivatives of the medial and lateral somite halves using quail-chick chimeras. Our results showed that the rhomboid muscles are made up of cells derived mainly from the lateral portion of the somite. Therefore the rhomboid muscles which lie within the epaxial domain of the body, originate from the hypaxial domain of the somites. However their connective tissue is derived from both medial and lateral somite. 


\section{Introduction}

The shoulder girdle, including the rhomboid muscles, underwent enormous transformations in the course of its evolutionary development. In bony fishes, the shoulder girdle is closely connected to the skull. But during evolution, it moved in the caudal direction, near to the trunk, implicating on the one hand independent movement of the skull, on the other hand independent movement of the upper limbs towards the trunk (Inuzuka 1992, McGonnell et al. 2001).

The rhomboid in mammals is made of several muscles. They function to stabilize the scapula, fixing it medially to the vertebral column. The human Mm. rhomboidei and the M. serratus anterior form a functional unit in this respect. Simultaneously, they work antagonistically by either fixing the scapula to the body or by pulling it dorsomedially and ventrolaterally.

While the embryonic origin of the other shoulder girdle muscles such as the trapezius and sternocleidomastoideus, pectoralis major and latissimus dorsi muscles are subject of many experimental studies, the origin and development of the rhomboid muscles remains a mystery. (Christ et al. 1976, Beresford et al. 1978, Chevallier 1979, Beresford 1983, Theis et al. 2010, Valasek et al. 2011).

The somites give rise to most of the skeletal muscle of the body (Christ and Ordahl 1995). Furthermore, it is well established, that somites consist of different compartments (BrandSaberi et al. 1996). Using quail-chick grafting experiments, Ordahl and Le Douarin and other authors showed that somites give rise to two different cell populations with specific developmental potential within these compartments (Ordahl and Le Douarin 1992, Huang and Christ 2000, Yusuf and Brand-Saberi 2006). The dorsomedial compartment generates the epaxial myotome, whereas the ventrolateral compartment gives rise to the hypaxial myotome (Ordahl and Le Douarin 1992, Huang and Christ 2000). The epaxial myotome provides the 
material for the intrinsic muscles of the back (Christ and Ordahl 1995, Huang and Christ 2000). The lateral dermomyotome (hypaxial domain) is source of progenitor cells of the limbs and the tongue, as well as the intercostal and abdominal muscles (Christ et al. 1977, Jacob et al. 1979, Christ and Ordahl 1995, Huang et al. 1999, Huang et al. 2001). The latter develop from hypaxial somitic buds that consist of an outer epithelial layer (lateral dermomyotome) and an inner layer of myotome cells.

The origin of the musculature of the shoulder girdle is heterogeneous ( $\mathrm{Pu}$ et al. 2016). The mammalian sternocleidomastoideus and trapezius muscles share a common embryonic source just like their avian homologue, the M. cucullaris. Cell tracing experiments have shown that the cucullaris muscle arises from the lateral plate mesoderm at the occipital level (Theis et al. 2010). In contrast, the latissimus dorsi and the pectoralis muscle originate from the wing bud and develop by a complex "In-Out" mechanism (Valasek et al. 2011, Masyuk et al. 2014).

The precursor cells of the rhomboid muscles have been assumed to originate from the hypaxial domain of the somites (Eisler 1912, Huang et al. 2000, Kardong 2002). However, Kent suggested that they develop from blastemas of the body wall and assigns them to the epaxial muscles, based on their topographic location (Kent 1973). Interestingly, investigations on the origin of the scapula in mouse and chicken embryos revealed that the scapular blade arises from the lateral halves of the cervicothoraxic dermomyotomes (Huang et al. 2000, Valasek et al. 2010). This is quite interesting since all other skeletal elements of the pelvic girdle originate from the lateral plate mesoderm (Christ et al. 2007, Malashichev et al. 2008). It can thus be reasoned that the scapula-connecting muscles, such as the rhomboid muscles, could also originate from the lateral halves of the thoracic dermomyotomes which would be in keeping with its innervation by ventral branches of the spinal nerves. 
1 To investigate the origin of the rhomboid muscles we have analysed quail-chick chimeras, in

2 which the medial and the lateral half of somites of chick embryos were replaced by equivalent

3 quail tissues (Wang et al. 2005, Wang et al. 2010). Our results demonstrate that the muscle

4 progenitor cells of the rhomboid muscles indeed originate from the hypaxial domain of the

5 somites. In addition, their connective tissue is derived from the epaxial and hypaxial domain

6 of somites.

7

8

9

\section{Materials and Methods}

\subsection{Embryos}

Fertilized eggs of the White Leghorn chick (Gallus gallus) and the Japanese quail (Coturnix coturnix japonica) were used for operation after incubation at $80 \%$ relative humidity and $37.8^{\circ} \mathrm{C}$. Staging of embryos was according to Hamburger and Hamilton (1951) and Ainsworth et al. (2010).

\subsection{Grafting procedure}

To investigate the origin of the rhomboid muscles, we carried out two series of experiments; homotopical transplantations of medial and lateral halves of epithelial somites with the following presomitic mesoderm, respectively. Details of the grafting procedure were described in our previous studies (Huang and Christ 2000, Wang et al. 2005, Wang et al. 2010). Briefly, the embryos were incubated for two days and operated at Hamburger and Hamilton $(\mathrm{HH})$-stage 13. After windowing the chicken eggs, PBS was dropped to prevent the embryo from drying out. After the vitelline membrane was cut with a tungsten wire needle overlying the embryos, a cut was made to divide the newly formed somite and the following unsegmented paraxial mesoderm into a medial and lateral half. At $\mathrm{HH}$-stage 13, the newly 
1 formed somite is located at the level somite 20. So in the most cases, the transplantation was

2 found at the level between somite 20 to somite 24 . For transplantation of the medial half of

3 somites, the medial somite halves were aspirated out using a mouth controlled glass capillary.

4 Then the equivalent quail tissue was transplanted to the position where the somite tissue was

5 removed. In the same way, the lateral somite halves were replaced through the equivalent

6 somite tissue from stage matched quail embryos. After the transplantation, the eggs were

7 sealed and reincubated for further 6-6.5 days.

\subsection{Immunohistochemistry}

Immunohistochemistry staining of sections of the chimeras was carried out according to the protocol described in our previous studies (Huang and Christ 2000, Wang et al. 2005, Wang et al. 2010). Briefly, quail cells were detected by an anti-quail antibody (QCPN) (Developmental Studies Hybridoma Bank, Iowa City, IA) and skeletal muscle cells were identified by an anti-desmin-antibody (Pu et al. 2012).

\section{Results}

The embryonic origin of the rhomboid muscles was studied in quail-chick chimeras, which were created by homotopic transplantation of the medial and lateral halves of somites and the following presomitic mesoderm (Wang et al. 2005, Wang et al. 2010). The transplantation was carried out at $\mathrm{HH}$-stage 13. The chimeras were fixed after 6 days of reincubation. From total 25 operations, 15 chimeras survived and were analyzed.

\subsection{Quail cells from the medial halves of somites contribute to the connective tissue of} the rhomboid muscles 
1 Results from this experiment series are based on assessment of 8 chimeras obtained from the transplantation of the medial halves of somites and presomitic mesoderm from quail embryos. All showed, quail cells in the vertebra (Fig. 1). The back dermis and the intrinsic back muscles were made up of mainly quail cells. In contrast, the distal rib and the scapular blade did not have any cells of quail origin. And no quail cells were found in the intercostals muscles and the limb muscles. This is a proof of the successful transplantation of the medial halves of somites. In these chimeras, all quail cells represented cells derived from the medial/epaxial domain of somites.

The rhomboid muscles in chick embryos are located medially to the scapular blade. Their medial part has tendon which connects the dorsal sheet of fascia of the intrinsic back muscles. Many quail cells were found in the medial part of the rhomboid muscles. Most of them did not express desmin and therefore are not myogenic. Based on their morphology and topography, they could be considered as cells of the tendon and muscle fascia. Most of muscle cells within the rhomboids were of chick origin (Fig. 1B, C). Noteworthy, the medial tendon of the latissimus dorsi muscle was made of quail cells.

These results suggest that the muscle progenitor cells of the rhomboids do not originate from the epaxial domain of the somites. However, the medial part of their connective tissue is derived from the epaxial somite tissue.

\subsection{Quail cells from the lateral halves of somites contribute to muscle cells and the connective tissue of the rhomboid muscles}

In all 7 chimeras in which transplantations of the lateral halves of the epithelial somite and presomitic mesoderm were performed, the vertebra was free from quail cells (Fig. 2). A few quail cells in the intrinsic back muscles and in the spinal cord were identifiable as endothelial cells through their morphology. This shows that no medial portions of somites were included into the grafts. 
1 In comparison to the first experimental series (medial somite transplantation), transplantations

2 of the lateral somite halves resulted in many quail cells in the rhomboid muscles (Fig. 2). The

3 quail-derived cells were distributed equally throughout the rhomboid muscles. They were

4 identified as both muscle and non-myogenic cells. Most of the non-myogenic quail cells were

5 connective tissue cells according to their cell morphology (Fig. 2B). As described in our

6 previous studies (Wang et al. 2005, Wang et al. 2010), the scapula blade was composed of

7 cells from the lateral somite halves (Fig. 2).

9 Our results indicate that the lateral somite, the hypaxial domain, gives rise to the myogenic cells of the rhomboid muscles. Furthermore, it contributes also to the majority of its connective tissue.

\section{Discussion}

In this study we document the embryological origin of the rhomboid muscles. Our aim was to determine whether muscle cells originate from the epaxial or hypaxial domain of the cervicothoracic somites. Previous studies have shown that the medial compartment of somites gives rise to the epaxial myotome, whereas the lateral compartment generates the hypaxial myotome (Ordahl and Le Douarin 1992, Huang and Christ 2000). While the epaxial domain is the source of the intrinsic back muscles (Huang and Christ 2000), the hypaxial domain gives rise to different muscle groups; the intrinsic muscles of the ventrolateral body wall (intercostals and abdominal muscles) (Chevallier 1979, Christ et al. 1983, Christ et al. 2007), limb muscles and superficial shoulder muscles (latissimus dorsi and pectoral muscle) (Chevallier et al. 1977, Christ et al. 1977, Chevallier 1979, Valasek et al. 2011). We show here that the rhomboid muscles which are medially located overlying the intrinsic back 
muscles, originate from the hypaxial domain of the somites. This is in agreement with their innervation by the supraclavicular portion of the plexus brachialis and in line with the assumption of several authors (Eisler 1912, Huang et al. 2000, Kardong 2002, Valasek et al. 2011, Pu et al. 2016). However, as they are situated dorsal to the vertebral column, this is an unexpected finding and it is still unclear how they move to occupy this position. c-Met (Prunotto et al. 2004) and Pax3 (Tremblay et al. 1998) null mouse have rhomboids preserved. Hence, the development of these muscles is non-migratory, independent of c-Met signalling.

Furthermore, the muscle fascia and the medial tendon of the rhomboids originate from the epaxial domain of the investigated somites. This suggests that the rhomboid muscles are the only muscles that undergo an exceptional dislocation from lateral to medial, thereby intermingling with connective tissue from the medial halves of the somites. This is in contrast to all other hypaxial muscles that migrate individually or as tissue sheets further laterally (Christ et al. 1977, Evans et al. 2006, Masyuk and Brand-Saberi 2015), either to stay in this position or to move back to the trunk backwards (Valasek et al. 2011, Masyuk and BrandSaberi 2015).

It is well known that the hypaxial muscles develop and translocate by two different mechanisms; either by extension of epithelial buds into the adjacent somatopleura as shown for the abdominal muscles (Christ et al. 1983) or by deepithelisation of the ventrolateral lips of the dermomyotomes and subsequent migration of the muscle progenitor cells to their destination (Bladt et al. 1995, Christ and Ordahl 1995, He et al. 2003, Pu et al. 2013). The latter is the case for muscles of the limbs and tongue (Christ et al. 1977, Jacob et al. 1978, Jacob et al. 1979, Huang et al. 1999, Huang et al. 2001).

The question how the myogenic progenitor cells get to the final position of the rhomboid muscles is still largely unanswered. We have followed the formation of the rhomboid muscles 
1 in immunohistochemical sections of normal chick embryos. We could not find any junction

2 between myotome, lateral dermomyotome lip and the rhomboid muscle blastem (data not

3 shown). Due to the fact of their innervation by the plexus brachialis, it is possible, that the

4 precursor cells detach from the dermomyotomes and migrate as undifferentiated myogenitor

5 cells in form of single mesenchymal cells to their destination in the epaxial region, where they

6 differentiate into muscle cells after the interaction with local connective tissue originated from

In their investigations Valasek et al. have observed that the rhomboid and the avian serratus muscles do not receive their progenitor cells from a population of outward migrating cells from the wing bud as the latissimus dorsi and pectoralis muscle do. That is why it is postulated, that the translocation mechanism of their myogenic cells differs from the mechanism of the other shoulder girdle muscles (Valasek et al. 2011). The translocation mechanism of the precursor cells of the so called superficial latissimus dorsi and pectoralis muscle can be divided into two different steps (Valasek et al. 2011); during myogenesis, the progenitor cells first migrate from the dermomyotomes into the limb bud. Then in a second step they migrate back to their final anatomical localisation (Valasek et al. 2011). This process was first described by Valasek and colleagues (Valasek et al. 2005). They examined the development of the avian cloacal muscles and demonstrated that these muscles also translocate by an "In-Out" mechanism (Valasek et al. 2005).

The rhomboid muscles and the blade of the avian scapula both develop from the lateral compartment of the somites (Huang et al. 2000, Huang et al. 2006, Valasek et al. 2010). Therefore we suggest that at the first step myogenic progenitor cells from the dermomyotome or primary muscle cells from the myotome find connection to the developing scapula blade. 
1 The pattern of the lateral part of the rhomboid muscle is determined through the connective

2 tissue which originates from the lateral somite. Then an elongation of the precursor mass in medial direction finalizes the formation of the whole muscle. The muscle precursor cells might be pulled from their lateral position into medial direction during scapular blade formation. And the form of the medial part of the rhomboid muscle should be patterned through the connective tissue from the medial somite. Hence, the rhomboid muscles can have an epaxial feature in their medial part. Similarly as the fascia of the intrinsic back muscle, the medial tendon of the rhomboid muscles is very thin and relatively long compared to the lateral part. Similar to the rhomboid muscles, the medial tendon of the latissimus dorsi muscle is also made of medial somite component (Fig. 1). In contrast, the lateral tendon of the rhomboid muscles is short and barely visible.

In addition to the classification in epaxial or hypaxial muscles, skeletal muscles can be divided into primaxial and abaxial muscles. The primaxial muscles develop within the connective tissue of the same domain, whereas the abaxial muscles migrate into the lateral plate mesoderm and grow within the connective tissue of the lateral plate mesoderm $(\mathrm{Pu}$ et al. 2016). According to these criteria, the intrinsic back muscles and the ventral neck muscles are primaxial. The abaxial muscles are the abdominal muscles and limb muscles. Based on the observation that the intercostal muscles develop in both somitic and lateral plate region, their vertebral part should be considered as primaxial, while the sternal part should be defined as the abaxial muscle (Aoyama et al. 2005). Due to their development within a region around the lateral somite frontier, some of the shoulder girdle muscles are purely primaxial and some are a mixture of prim- and adaxial (Pu et al. 2016). Since the rhomboid muscles develop medial to the scapula blade which is formed by somitic tissue, they can be defined as primaxial muscle. 
1 In comparative studies Abdala and Diogo have proposed that the attachment points of the

2 rhomboid muscles in avians, anurans and crocodiles are located at the same regions as those

3 of the mammalian rhomboids. Furthermore, they have suggested that the morphology of the

4 rhomboid muscles of the examined amphibians and amniotes remains the same (Abdala and

5 Diogo 2010). Therefore the question arises, if during evolution the morphology of the

6 rhomboid muscles developed independently in different taxa or if phylogenetic convergence

7 has led to the same morphology. The answer to this question by means of comparative

8 embryology studies and molecular investigations might explain the underlying intrinsic

9 molecular mechanisms during the development of the rhomboid muscles.

\section{Conclusion}

In conclusion, our grafting experiments show that muscle cells of the rhomboid muscles originate from the hypaxial domain of the somite. However, their connective tissue originates from both epaxial and hypaxial domain.

\section{Acknowledgements}

We are grateful for the technical assistance of Sandra Graefe. We thank Developmental

Studies Hybridoma Bank, Iowa City, IA, USA for the QCPN-antibody. This work was supported by grant of the DFG-729/10 to R.H.

\section{References}

Abdala, V. and Diogo, R. (2010) 'Comparative anatomy, homologies and evolution of the pectoral and forelimb musculature of tetrapods with special attention to extant limbed amphibians and reptiles', J Anat, 217(5), 536-73. 
Ainsworth, S. J., Stanley, R. L. and Evans, D. J. (2010) 'Developmental stages of the Japanese quail', J Anat, 216(1), 3-15.

Aoyama, H., Mizutani-koseki, S. and Koseki, H. (2005) 'Three developmental compartments involved in rib formation', Int J Dev Biol, 49(2-3), 325-33.

Beresford, B. (1983) 'Brachial muscles in the chick embryo: the fate of individual somites', J Embryol Exp Morphol, 77, 99-116.

Beresford, B., Le Lievre, C. and Rathbone, M. P. (1978) 'Chimaera studies of the origin and formation of the pectoral musculature of the avian embryo', Journal of Experimental Zoology, 205(2), 321-326.

Bladt, F., Riethmacher, D., Isenmann, S., Aguzzi, A. and Birchmeier, C. (1995) 'Essential role for the cmet receptor in the migration of myogenic precursor cells into the limb bud', Nature, 376(6543), 768-71.

Brand-Saberi, B., Wilting, J., Ebensperger, C. and Christ, B. (1996) 'The formation of somite compartments in the avian embryo', Int J Dev Biol, 40(1), 411-20.

Chevallier, A. (1979) 'Role of the somitic mesoderm in the development of the thorax in bird embryos. II. Origin of thoracic and appendicular musculature', J Embryol Exp Morphol, 49, 73-88.

Chevallier, A., Kieny, M. and Mauger, A. (1977) 'Limb-somite relationship: origin of the limb musculature', J Embryol Exp Morphol, 41, 245-58.

Christ, B., Huang, R. and Scaal, M. (2007) 'Amniote somite derivatives', Dev Dyn, 236(9), 2382-96.

Christ, B., Jacob, H. and Jacob, M. (1976) 'Über die Herkunft der Mm. pectorales major et minor. Experimentelle Untersuchungen an Wachtel- und Hühnerembryonen', Verh Anat Ges 70, 1007-1011.

Christ, B., Jacob, H. J. and Jacob, M. (1977) 'Experimental analysis of the origin of the wing musculature in avian embryos', Anatomy and Embryology, 150(2), 171-186.

Christ, B., Jacob, M. and Jacob, H. J. (1983) 'On the origin and development of the ventrolateral abdominal muscles in the avian embryo. An experimental and ultrastructural study', Anat Embryol (Berl), 166(1), 87-101.

Christ, B. and Ordahl, C. P. (1995) 'Early stages of chick somite development', Anat Embryol (Berl), 191(5), 381-96. 
Eisler, P. (1912) ' Die Muskeln des Stammes' in Handbuch der Anatomie des Menschen in acht Bänden, Jena: Bardeleben, Kv, 1-699.

Evans, D. J., Valasek, P., Schmidt, C. and Patel, K. (2006) 'Skeletal muscle translocation in vertebrates', Anat Embryol (Berl), 211 Suppl 1, 43-50.

He, L., Papoutsi, M., Huang, R., Tomarev, S. I., Christ, B., Kurz, H. and Wilting, J. (2003) 'Three different fates of cells migrating from somites into the limb bud', Anat Embryol (Berl), 207(1), 29-34.

Huang, R. and Christ, B. (2000) 'Origin of the epaxial and hypaxial myotome in avian embryos', Anat Embryol (Berl), 202(5), 369-74.

Huang, R., Christ, B. and Patel, K. (2006) 'Regulation of scapula development', Anat Embryol (Berl), 211 Suppl 1, 65-71.

Huang, R., Lang, E. R., Otto, W. R., Christ, B. and Patel, K. (2001) 'Molecular and cellular analysis of embryonic avian tongue development', Anat Embryol (Berl), 204(3), 179-87.

Huang, R., Zhi, Q., Izpisua-Belmonte, J. C., Christ, B. and Patel, K. (1999) 'Origin and development of the avian tongue muscles', Anat Embryol (Berl), 200(2), 137-52.

Huang, R., Zhi, Q., Patel, K., Wilting, J. and Christ, B. (2000) 'Dual origin and segmental organisation of the avian scapula', Development, 127(17), 3789-94.

Inuzuka, N. (1992) 'Evolution of the shoulder girdle with special reference to the problems of the clavicle', J Anthrop Soc Nippon, 100(4), 391-404.

Jacob, M., Christ, B. and Jacob, H. J. (1978) 'On the migration of myogenic stem cells into the prospective wing region of chick embryos. A scanning and transmission electron microscope study', Anat Embryol (Berl), 153(2), 179-93.

Jacob, M., Christ, B. and Jacob, H. J. (1979) 'The migration of myogenic cells from the somites into the leg region of avian embryos. An ultrastructural study', Anat Embryol (Berl), 157(3), 291-309.

Kardong, K. V., Ph. D. (2002) 'Vertebrates: comparative anatomy, function, evolution', 3rd ed. p. cm.

Kent, G. C. (1973) 'Comparative anatomy of the vertebrates', Third edition.

Malashichev, Y., Christ, B. and Prols, F. (2008) 'Avian pelvis originates from lateral plate mesoderm and its development requires signals from both ectoderm and paraxial mesoderm', Cell Tissue Res, 331(3), 595-604. 
Masyuk, M., Abduelmula, A., Morosan-Puopolo, G., Odemis, V., Rehimi, R., Khalida, N., Yusuf, F., Engele, J., Tamamura, H., Theiss, C. and Brand-Saberi, B. (2014) 'Retrograde migration of pectoral girdle muscle precursors depends on CXCR4/SDF-1 signaling', Histochem Cell Biol, 142(5), 473-88.

Masyuk, M. and Brand-Saberi, B. (2015) 'Recruitment of skeletal muscle progenitors to secondary sites: a role for CXCR4/SDF-1 signalling in skeletal muscle development', Results Probl Cell Differ, 56, 1-23.

McGonnell, I. M., McKay, I. J. and Graham, A. (2001) 'A population of caudally migrating cranial neural crest cells: Functional and evolutionary implications', Dev Biol, 236(2), 354-363.

Ordahl, C. P. and Le Douarin, N. M. (1992) 'Two myogenic lineages within the developing somite', Development, 114(2), 339-53.

Prunotto, C., Crepaldi, T., Forni, P. E., leraci, A., Kelly, R. G., Tajbakhsh, S., Buckingham, M. and Ponzetto, C. (2004) 'Analysis of Mlc-lacZ Met mutants highlights the essential function of Met for migratory precursors of hypaxial muscles and reveals a role for Met in the development of hyoid arch-derived facial muscles', Dev Dyn, 231(3), 582-91.

Pu, Q., Abduelmula, A., Masyuk, M., Theiss, C., Schwandulla, D., Hans, M., Patel, K., Brand-Saberi, B. and Huang, R. (2013) 'The dermomyotome ventrolateral lip is essential for the hypaxial myotome formation', BMC Dev Biol, 13, 37.

Pu, Q., Christ, B. and Huang, R. (2012) 'Temporal sequence in the formation of midline dermis and dorsal vertebral elements in avian embryos', J Anat, 221(2), 115-20.

Pu, Q., Huang, R. and Brand-Saberi, B. (2016) 'Development of the shoulder girdle musculature', Dev Dyn, 245(3), 342-50.

Theis, S., Patel, K., Valasek, P., Otto, A., Pu, Q., Harel, I., Tzahor, E., Tajbakhsh, S., Christ, B. and Huang, R. (2010) 'The occipital lateral plate mesoderm is a novel source for vertebrate neck musculature', Development, 137(17), 2961-71.

Tremblay, P., Dietrich, S., Mericskay, M., Schubert, F. R., Li, Z. and Paulin, D. (1998) 'A Crucial Role forPax3in the Development of the Hypaxial Musculature and the Long-Range Migration of Muscle Precursors', Developmental Biology, 203(1), 49-61.

Valasek, P., Evans, D. J., Maina, F., Grim, M. and Patel, K. (2005) 'A dual fate of the hindlimb muscle mass: cloacal/perineal musculature develops from leg muscle cells', Development, 132(3), 447-58.

Valasek, P., Theis, S., DeLaurier, A., Hinits, Y., Luke, G. N., Otto, A. M., Minchin, J., He, L., Christ, B., Brooks, G., Sang, H., Evans, D. J., Logan, M., Huang, R. and Patel, K. (2011) 'Cellular and 
molecular investigations into the development of the pectoral girdle', Dev Biol, 357(1), 10816.

Valasek, P., Theis, S., Krejci, E., Grim, M., Maina, F., Shwartz, Y., Otto, A., Huang, R. and Patel, K. (2010) 'Somitic origin of the medial border of the mammalian scapula and its homology to the avian scapula blade', J Anat, 216(4), 482-8.

Wang, B., He, L., Ehehalt, F., Geetha-Loganathan, P., Nimmagadda, S., Christ, B., Scaal, M. and Huang, R. (2005) 'The formation of the avian scapula blade takes place in the hypaxial domain of the somites and requires somatopleure-derived BMP signals', Dev Biol, 287(1), 11-8.

Wang, B., Pu, Q., De, R., Patel, K., Christ, B., Wilting, J. and Huang, R. (2010) 'Commitment of chondrogenic precursors of the avian scapula takes place after epithelial-mesenchymal transition of the dermomyotome', BMC Dev Biol, 10, 91.

Yusuf, F. and Brand-Saberi, B. (2006) 'The eventful somite: patterning, fate determination and cell division in the somite', Anat Embryol (Berl), 211 Suppl 1, 21-30.

\section{Legend}

Figure 1. Quail-chick chimera after transplantation of the medial halves of an epithelial somite and the following presomitic mesoderm. A)-C) Show an immunostained cross-section of an about 8.5 days old chicken embryo after 6.5 days of reincubation. The muscle cells are stained dark brown. Quail cell nuclei are blue dots. A) Overview of the operation region. Quail cells are found in the vertebra (v) and intrinsic back muscles (i) as well as the back dermis (d). The scapular blade (s) is free from quail cells. The rhomboid muscles (r) which extend from the medial margin of the scapula blade to the dorsal sheet of the intrinsic back muscles consist of quail cells in their medial part. The medial tendon of the latissimus dorsi muscle (l) is made of quail cells. Magnification of the rhomboid muscles (r) are shown in B) + C). B) In the medial part of the rhomboid muscles (r), most of quail cells are non-myogenic cells, only very few cells have colocalization of desmin (dark bown) and quail nuclei (blue dots). This part is further twofold enlarged in C). 
2 Figure 2. Quail-chick chimera after transplantation of the lateral halves of the epithelial 3 somite and presomitic mesoderm. A)-B) Show an immunostained cross-section of an about 8 4 days old chicken embryo after 6 days of reincubation. A) Overview of the operation region. 5 The vertebra (v) and intrinsic back muscles (i) are free from quail cells. The scapular blade (s) 6 consists of many quail cells (with blue nuclei). Cartilaginous differentiation is not yet 7 advanced. The rhomboid muscles (r) located in the medial side of the scapula (s) are 8 composed of quail cells. B) Magnification of the rhomboid muscles (r). Cells of both 9 myogenic and connective component are of quail origin. 


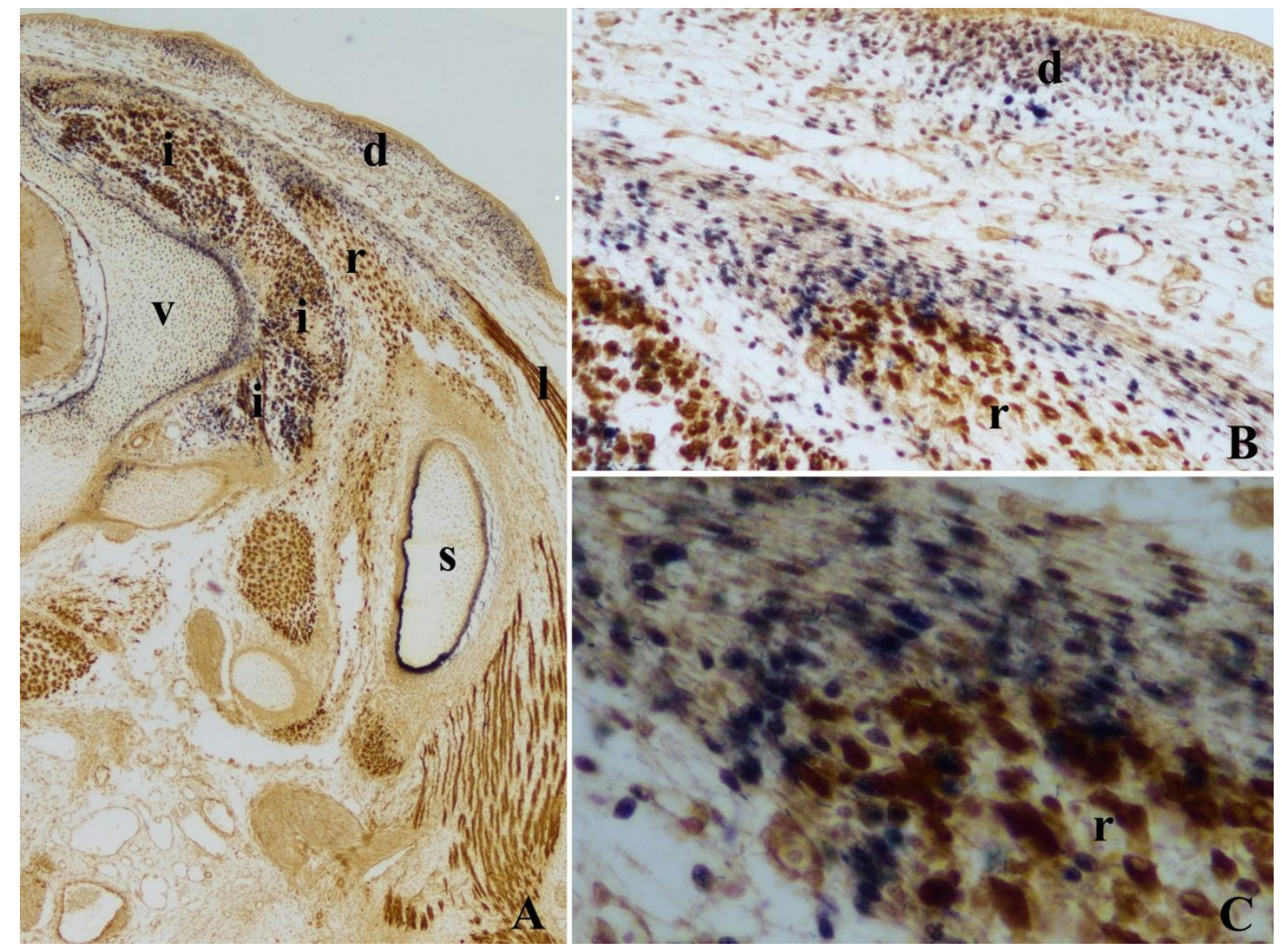




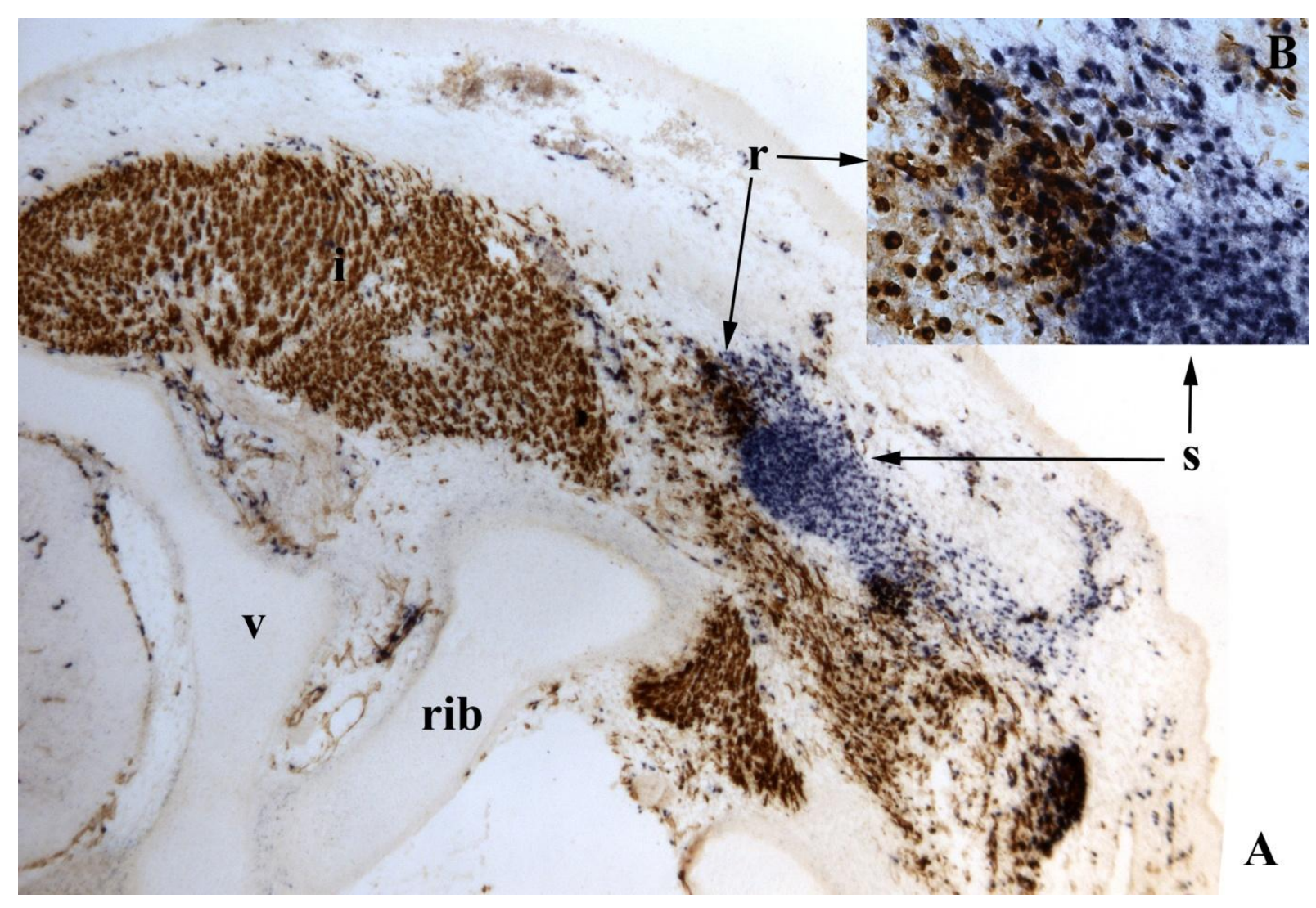

Figure 2

\section{Figure 2}

A 